\title{
Nitrogen and row spacing on Digitaria eriantha production and digestibility
}

\author{
ALFREDO O. GARGANO, MIGUEL A. ADÚRIZ, CARLOS A. BUSSO, AND MARÍA I. AMELA
}

Authors are Professor and Researcher of the Consejo Nacional de Investigaciones Científicas y Técnicas de la República Argentina (CONICET), Departamento de Agronomía and CERZOS, Universidad Nacional del Sur (UNSur), 8000 - Bahía Blanca, Argentina, Assistant Professor, Departamento de Agronomía UNSur, Professor and researcher of CONICET, Departamento de Agronomía and CERZOS, UNSur, and Assistant Professor, Departamento de Agronomía UNSur.

\section{Abstract}

Research on the effects of the rate and method of fertilizer application or row spacing on dry matter yield and digestibility of perennial forage crops either is scarce or has produced contradictory results. The objective of this study was to determine the effects of various rates of $\mathbf{N}$ fertilization, method of fertilizer application and row spacing on dry matter yields and in vitro dry matter digestibility (IVDMD) in the cultivated, perennial forage grass Digitaria eriantha Steud. subsp. eriantha cv. Irene. Field studies were conducted on a petrocalcic Ustipsament, sandy loam soil. The total annual $N$ fertilizer $\left(0,50\right.$ or $\left.100 \mathrm{~kg} \mathrm{ha}^{-1}\right)$ was applied once (in early spring) or split (half in early spring, half in early summer) on rows 0.3 or $0.5 \mathrm{~m}$ apart. Plants were clipped, leaving $50 \mathrm{~mm}$ of stubble, whenever they reached $260-280 \mathrm{~mm}$ height during the 1998-1999 and 1999-2000 growing seasons. All fertilized treatments produced higher $(P<0.05)$ dry matter yields than unfertilized controls. Averaged across both seasons, annual dry matter yields were $3.5,5.2$, and $6.0 \mathrm{Mg} \mathrm{ha}^{-1}$ for 0,50 , and $100 \mathrm{~kg} \mathrm{ha}^{-1} \mathrm{~N}$ treatments, respectively. Dry matter yields during summer were greater $(P<0.05)$ under split than single application. Row spacing did not affect dry matter yield. Although small, increases in IVDMD due to fertilization were significant $(P<0.05)$. Mean IVDMD was 602,633 , and $656 \mathrm{~g} \mathrm{~kg}^{-1}$ for $\mathrm{N}$ fertilization rates of 0,50 , and $100 \mathrm{~kg} \mathrm{ha}^{-1}$. It is suggested that $\mathrm{N}$ application should be between 50 and $100 \mathrm{~kg} \mathrm{ha}^{-1}$ for $D$. eriantha, and that this application should be split rather than applied at one time in early spring.

Key Words: forage yield and quality, perennial forage grasses, semiarid Argentina, fertilization

Digitaria eriantha Steud. subsp. eriantha cv. Irene is of the warm-season perennial forage grasses utilized in livestock production systems of semiarid environments. This species, native to South Africa (Rethman et al. 1997), has a great adaptive capacity, a high production potential and a clear, positive response to $\mathrm{N}$ fertilization (Rethman 1987, Dannhauser 1991, Pieterse and Rethman 1995). It has not, however, always produced satisfactory responses in terms of animal production. While Grunow et al. (1984) reported improved individual and per hectare weight gains in cattle, production increases were scarce in sheep (Van Vuuren

\footnotetext{
Research was funded by the Universidad Nacional del Sur
}

Manuscript accepted 16 Nov. 02.

\section{Resumen}

Las investigaciones sobre los efectos de la forma de aplicación de fertilizantes o espaciamiento entre hileras en la producción y digestibilidad de la materia seca en especies forrajeras cultivadas perennes son escasas o han producido resultados contradictorios. El objetivo de este estudio fue determinar los efectos de varias tasas de fertilización nitrogenada, forma de aplicación del fertilizante y espaciamiento entre hileras en los rendimientos de materia seca $y$ en la digestibilidad in vitro de la materia seca (DIVMS) en la gramínea forrajera cultivada perenne Digitaria eriantha Steud. subsp. eriantha cv. Irene. Los estudios fueron conducidos a campo en un suelo perteneciente al subgrupo Ustipsament petrocálcico. La fertilización total anual de $N(0,50$, ó $100 \mathrm{~kg} \mathrm{ha}^{-1}$ ) fue aplicada de una sola vez a principios de primavera o dividida, la mitad a principios de primavera y la otra mitad a principios del verano, en hileras separadas 0.3 ó $0.5 \mathrm{~m}$ entre sí. Las plantas fueron cortadas a $50 \mathrm{~mm}$ desde el nivel del suelo toda vez que alcanzaron $260-280 \mathrm{~mm}$ de altura durante las estaciones de crecimiento de 1998-1999 y 1999-2000. Todos los tratamientos fertilizados mostraron una mayor $(P<0.05)$ producción de materia seca que los controles no fertilizados. Los rendimientos de materia seca anuales fueron $3.5,5.2$, y $6.0 \mathrm{Mg}$ ha-1 en los tratamientos no fertilizados y en aquellos que recibieron 50 y $100 \mathrm{~kg} \mathrm{ha}^{-1}$, respectivamente en promedio para ambas estaciones. Los rendimientos de materia seca durante el verano fueron mayores $(P<0.05)$ cuando la aplicación del fertilizante fue dividida que cuando se efectuó de una sola vez. El espaciamiento entre hileras no afectó los rendimientos de materia seca. Aunque pequeños, los incrementos en la DIVMS debidos a la fertilización fueron significativos $(P<\mathbf{0 . 0 5})$. La DIVMS promedio fue de 602, $633, y 656 \mathrm{~g} \mathrm{~kg}^{-1}$ para tasas de fertilización nitrogenada de $0,50 \mathrm{y}$ $100 \mathrm{~kg} \mathrm{ha}^{-1}$. Se sugiere que la fertilización con $\mathrm{N}$ en $D$. eriantha debería oscilar entre 50 y $100 \mathrm{~kg} \mathrm{ha}^{-1}$ y que la aplicación fuera preferiblemente dividida en vez de una sola vez a principios de primavera.

et al. 1997). In Argentina, promising responses in terms of forage production have been obtained for this species in the Provinces of La Pampa and San Luis (Stritzler et al. 1986, Veneciano and Terenti 1997), while in Buenos Aires Province experimental information has become available only in the last few years (Gargano et al. 2001a, 2001b). These responses in forage yields are due to an improved management of $D$. eriantha.

The method of $\mathrm{N}$ fertilization of $D$. eriantha has produced some contradictory results on dry matter yields. Rethman (1987) rec- 
ommended split $\mathrm{N}$ fertilization for this species to adjust rates of $\mathrm{N}$ fertilizer to precipitation regimes. Other authors have fertilized $D$. eriantha by applying $127 \mathrm{~kg}$ $\mathrm{ha}^{-1} \mathrm{~N}$ in 3 unequal amounts during November through February based upon the phenology of this species (Veneciano and Terenti 1997). However, Pieterse and Rethman (1995) suggested that N fertilization of $D$. eriantha should be made once during the growing season. Their suggestion was based on the observation that split fertilization did not increase productivity in $D$. eriantha. Given that the method of $\mathrm{N}$ fertilization has produced such contradictory results, we decided to test whether split or at once application of $\mathrm{N}$ during the growing season would improve dry matter yields in $D$. eriantha.

Another factor which may influence dry matter yields in the field is row spacing of plants. Although most research evaluating the effects of row spacing on dry matter yields has been conducted on row crops (Natr 1976, Farnham 2001), some studies have been conducted on perennial forage grasses (Kruger and Smit 1974, Muir et al. 2001). Depending on the plant establishment phase, results reported in these studies range from no effect to increases or decreases in dry matter yields as spacing among rows becomes narrower (Muir et al. 2001). Thus, determination of row spacing in productivity of perennial forage crops is important since dry matter yields can be affected. While the effects of $\mathrm{N}$ fertilizer have been partially addressed in $D$. eriantha (i.e. Rethman et al. 1987, Pieterse and Rethman 1995), row spacing and quality have not in this species, which makes our study unique in this regard.

The objective of this study was to determine the effects of different rates of $\mathrm{N}$ fertilization, method of fertilizer application and row spacing on $D$. eriantha forage production and quality. These studies will advance the knowledge of this species' performance under varying management conditions.

\section{Materials and Methods}

\section{Study Area}

Field experiments were conducted over 2 years (1998-1999 and 1999-2000) at the Universidad Nacional del Sur research facility in Bahía Blanca $\left(38^{\circ} 48^{\prime} \mathrm{S}, 62^{\circ}\right.$ $\left.13^{\prime} \mathrm{W}\right)$, Argentina. Soil belongs to the subgroup petrocalcic Ustipsament (USDA 1999). It has a sandy-loam texture, and is low in organic matter and highly susceptible to wind erosion (Sánchez and Kruger 1981). A meteorological station located at the study site provided rainfall and temperature data. During the 7-month growing period (September through March), rainfall was $448 \mathrm{~mm}$ in 1998-1999 and $469 \mathrm{~mm}$ in 1999-2000. Average annual rainfall during the last 10 years is $483 \mathrm{~mm}$ for the same period (Servicio Meteorológico Nacional 2000).

\section{Experimental Procedures}

Experimental plots were disked in June 1997, harrowed in mid-October, and the seed bed was then hand-smoothed using a rake. Plots were seeded on 23 Oct. 1997 using a manual monofurrow machine which allowed control of seeding depth, and had a wheel to produce compaction of the row. Pelleted seeds with $60 \%$ cultural value (\% seed purity $\mathrm{x} \%$ germination) were seeded at a depth of $0.015 \mathrm{~m}$ and rate of $4 \mathrm{~kg} \mathrm{ha}^{-1}$. From seedling emergence onward, weeds were controlled by hoeing.

\section{Experimental Design and Treatments}

The experiment was a split-plot in a randomized complete block design with row spacing and $\mathrm{N}$ fertilization rates as main plots and method of fertilization as subplots. Nitrogen was applied at 0,50 , and $100 \mathrm{~kg} \mathrm{ha}^{-1}$ during each season on row spacings of 0.3 or $0.5 \mathrm{~m}$. The total amount of $\mathrm{N}$ was applied as urea (46-0-0) either all at once in early spring (22 September in 1998/1999; 23 September in 1999/2000) or split applied: half in early spring and the other half in early summer (22 December in both years). Timing of urea applications were made to coincide with a rainfall or irrigation event equivalent to $3-4 \mathrm{~mm}$ to allow for its disolution and penetration in the soil. Blocks were $5 \mathrm{~m}$ apart one from another. Each of the 3 blocks was composed of 6 main plots: 3 plots were $4.5 \mathrm{x}$ $1.2 \mathrm{~m}$ each with row spacings of $0.3 \mathrm{~m}$, and the other 3 plots were $4.5 \times 2.0 \mathrm{~m}$ each with row spacings of $0.5 \mathrm{~m}$.

The experimental design in spring used blocks with unequal number of replicates because $\mathrm{N}$ application was fractionated (Table 1). We used a 2-way ANOVA to analyze this information. There were 8 treatments as a result of combining 4 rates of $\mathrm{N}$ fertilizer $\left(0,25,50\right.$, and $100 \mathrm{~kg} \mathrm{ha}^{-1}$ $\mathrm{N})$ and 2 row spacings (Table 1). The 25 $\mathrm{kg} \mathrm{ha}^{-1} \mathrm{~N}$ rate was the result of spring and summer split application of $50 \mathrm{~kg} \mathrm{ha}^{-1} \mathrm{~N}$. As a result, each row spacing had 2 subplots (replicates) of the 0 and $50 \mathrm{~kg} \mathrm{ha}^{-1} \mathrm{~N}$ and 1 subplot (replicate) of the 25 and 100 $\mathrm{kg} \mathrm{ha}^{-1} \mathrm{~N}$ within each block (see Table 1). The experimental design during summer and that resulting from applying $\mathrm{N}$ all at
Table 1. Total annual amount of $\mathbf{N}$ fertilization, and rate of $\mathbf{N}$ application when the fertilizer was applied split or all at once at row spacings of either 30 or $50 \mathrm{~cm}$.

\begin{tabular}{cccc}
\hline \hline Total annual \\
amount of N & $\begin{array}{c}\text { Spring } \\
(\mathrm{Sp})\end{array}$ & $\begin{array}{c}\text { Summer } \\
(\mathrm{Su})\end{array}$ & $\begin{array}{c}\text { At once } \\
\text { Spring } \\
(\mathrm{Sp})\end{array}$ \\
\hline & $-\cdots$ & $\left(\mathrm{kg} \mathrm{ha}^{-1}\right)$ & $-\cdots--$ \\
0 & 0 & 0 & 0 \\
50 & 25 & 25 & 50 \\
100 & 50 & 50 & 100 \\
\hline
\end{tabular}

once in early spring was split blocks; each block remaining was divided into 12 subplots, 1 per treatment. We thus used a 3way ANOVA for studying summer and total results $(3$ rates of $\mathrm{N}$ fertilizer $\mathrm{x} 2$ row spacings $x 2$ methods of fertilizer application). There were 3 replicates, 1 per block, for each treatment combination.

\section{Measurements and Analytical Procedures}

Forage grown during 1997-1998 was clipped to $50-\mathrm{mm}$ stubble height during mid- winter (August) and removed from the plots, prior to spring regrowth in 1998. Thus, only current-year growth was included in each season. Subsequently, plants were clipped to $50 \mathrm{~mm}$ stubble whenever they reached $260-280 \mathrm{~mm}$ height during the growing season. Spring or summer dry matter yields include all clippings made from September to midDecember or mid-December to early April, respectively. Total annual dry matter yield was calculated by summing up yields of spring plus summer. The first clipping took place on 25 October in 1998 and 16 November in 1999. The average number of spring harvests was 3.5 in 1998 and 2.0 in 1999 . Total number of harvests ranged from 7 to 9 during 1998-1999 and 4 to 5 during 1999-2000 (see Fig. 1). All plant material clipped within each plot at a distance of $0.5 \mathrm{~m}$ from its periphery was discarded. The remaining forage within each plot was used for dry matter determinations. Dry matter yield and IVDMD were measured on forage harvested in spring or summer. Harvested forage was dried at $60^{\circ} \mathrm{C}$ and weighed. Forage samples coming from either spring or summer harvests were combined for each subplot within each season and ground to pass a 1 mm-mesh screen for analysis of IVDMD following Barnes (1966). In vitro dry matter digestibility of total annual dry matter yield was calculated from spring and summer determinations. Digestible dry matter yields were calculated by multiplying dry matter yields and IVDMD. 
1998-1999

SPLIT FERTILIZATION

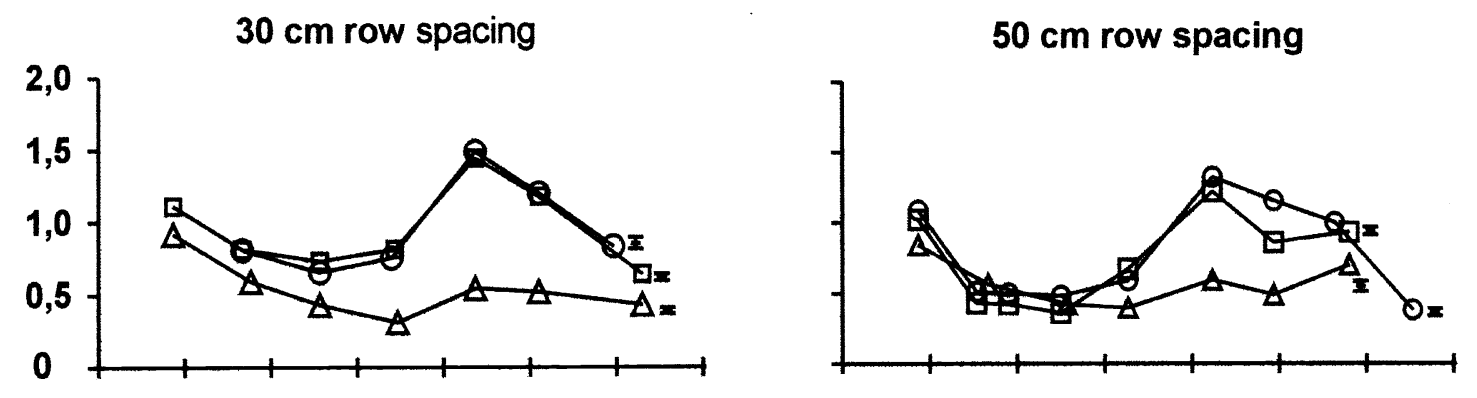

TOTAL FERTILIZATION
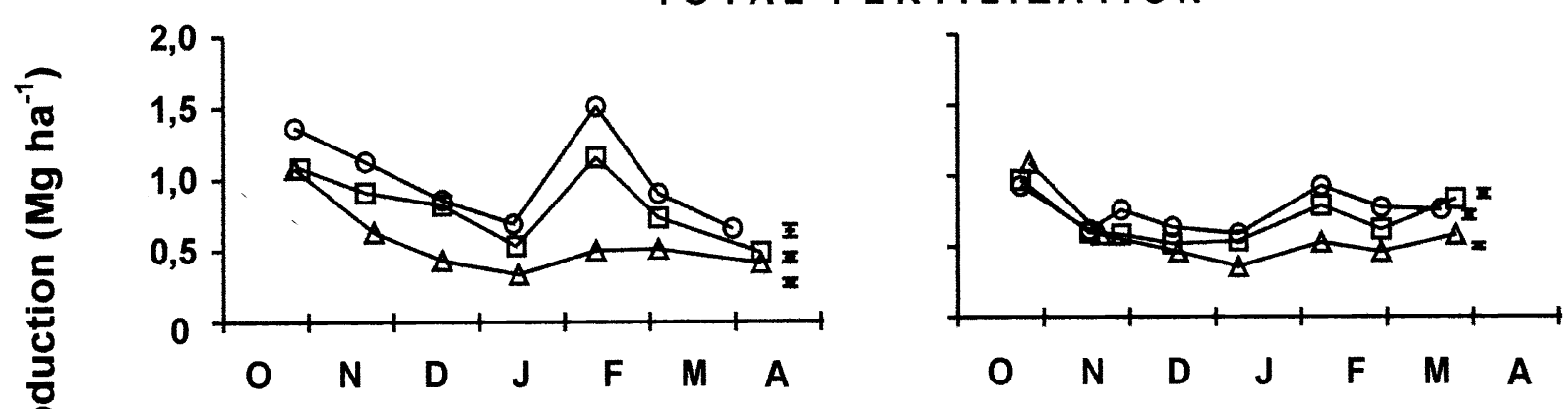

1999-2000

SPLIT FERTILIZATION
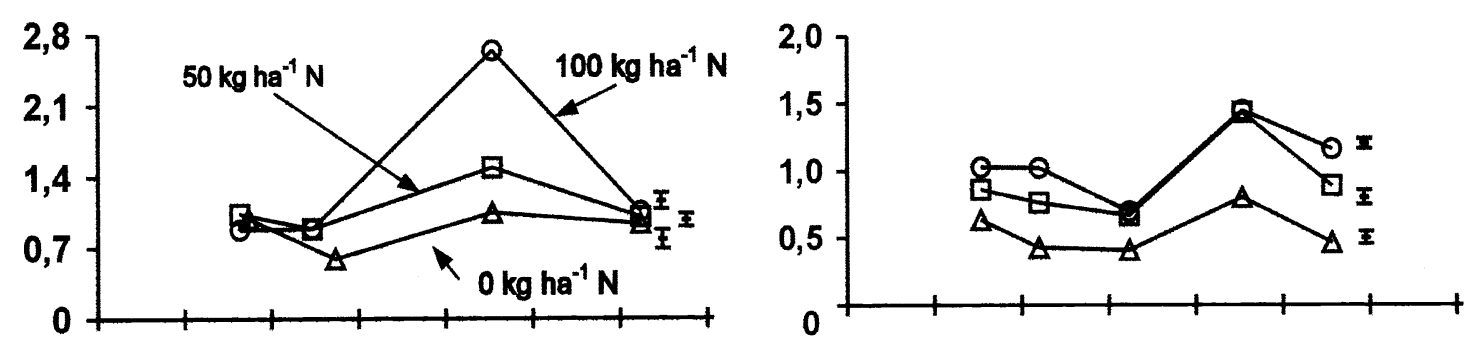

TOTAL FERTILIZATION
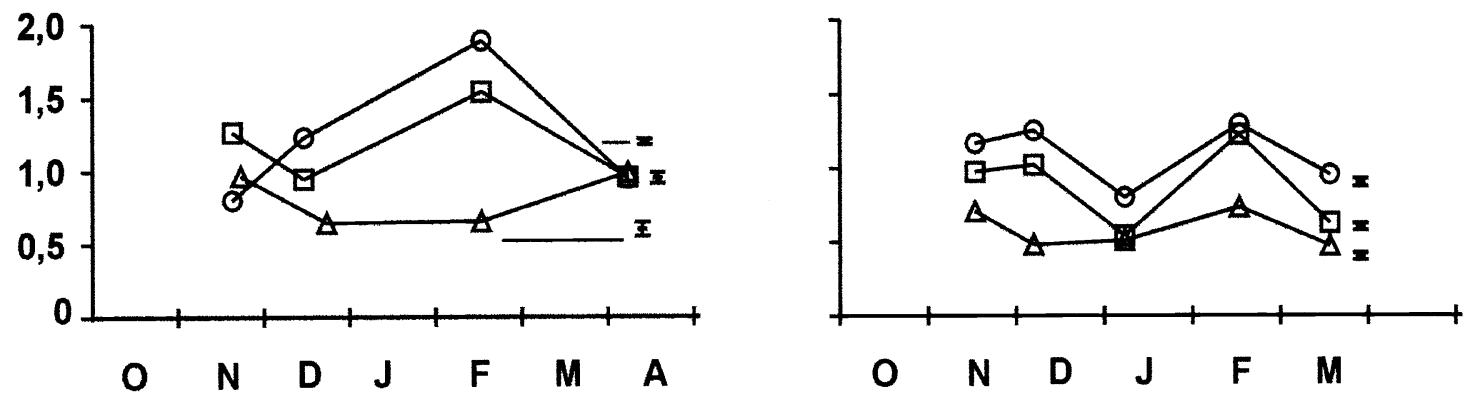

\section{Clipping dates}

Fig. 1. Dry matter yields at each clipping date as affected by row spacing and method and rate of $\mathrm{N}$ fertilization during 1998-99 and 1999-00. Each value is an average of $n=3$. Vertical bars indicate $2 x$ the average $S E$ of the means for each $N$ fertilization rate. Note the change of scale in $1999-00$ under split fertilization and $0.3 \mathrm{~m}$ row spacing. 


\section{Statistical Analysis}

Spring determinations were analyzed using 2-way ANOVA with unbalanced blocks but proportional replicates. A 3way ANOVA with split blocks was used to analyze summer and total annual yields and IVDMD. When interactions occurred, multiple comparisons were conducted using the combined mean square error which was obtained from the formula of Satterthwaite (Steel and Torrie 1988). Yield and IVDMD differences were determined using the least significant difference test, although a t test was used when average dry matter yields under split fertilization were compared with those under single fertilization.

\section{Results and Discussion}

\section{Dry Matter Yields}

Spring and summer were analyzed separately since treatments interacted significantly $(P<0.05)$ with seasons for spring, summer or total annual dry matter yields. A significant $(\mathrm{P}<0.05)$ interaction was also found between rate of $\mathrm{N}$ fertilizer and row spacing in the spring of 1998-1999 and 1999-2000 (Table 2). Except at $0.3 \mathrm{~m}$ row spacing, for which $\mathrm{N}$ fertilization rates of 25 and $50 \mathrm{~kg} \mathrm{ha}^{-1}$ did not differ $(\mathrm{P}$ $>0.05$ ), spring dry matter yields increased $(\mathrm{P}<0.05)$ as fertilization rates increased in both row spacings during 1998-1999 (Table 2). Yield increase with increased $\mathrm{N}$ fertilization is a frequent response in cultivated perennial grass species, although plant responses to fertilization are highly dependent on subsequent precipitation levels (Hernández 1991, Pieterse and Rethman 1995, Jacobsen et al. 1996, Veneciano and Terenti 1997). Total spring yields at $0.3 \mathrm{~m}$ row spacing were similar or greater, but not lower, than those at 0.5 m (Table 2). Muir et al. (2001) reported that biomass decreased as row spacing increased during plant establishment years in Panicum virgatum. These authors suggested that it may be advantageous to plant $P$. virgatum in narrow rows (aproximately $0.25 \mathrm{~m}$ ) to maximize production during establishment. Narrow row spacing, however, may decrease biomass production during some years after establishment in this species (Muir et al. 2001). The advantage of narrow row spacing during the establishment years, nevertheless, may outweight disadvantages in later years.

In spring, dry matter yields were lower in 1999-2000 than in 1998-1999 (Table 2). This may be due to a couple of reasons. First, plants clipped in spring 1999 had been clipped in the previous spring. Several studies have shown that repeated clipping of the same plants over consecutive years will reduce dry matter yields of perennial grasses (Stout et al. 1981, Becker et al. 1997). Second, there was a wider range between temperature extremes in October during the second than the first season. Even though October is often a temperate month (Servicio Meteorológico Nacional 2000), absolute maximum temperatures reached $35^{\circ} \mathrm{C}$ and absolute minimum temperatures fell below freezing in October 1999. As a result, the first clipping was delayed and the total number of spring clippings was lower (Fig. 1) in 1999 than in 1998. Similar results of increased dry matter yields with increased $\mathrm{N}$ fertilization were obtained in 1999-2000 for both row spacings (Table 2). Except at the highest rate of $\mathrm{N}$ fertiliza-

Table 2. Spring dry matter yields as influenced by row spacing and $\mathbf{N}$ fertilization rates in 1998-99 and 1999-00. Values are means \pm 1 standard error.

\begin{tabular}{|c|c|c|c|c|c|}
\hline \multirow[b]{2}{*}{ Season } & \multirow{2}{*}{$\begin{array}{c}\text { Row } \\
\text { spacing }\end{array}$} & \multicolumn{4}{|c|}{$\mathrm{N}$ fertilization rates $\left(\mathrm{kg} \mathrm{ha}^{-1}\right)$} \\
\hline & & 0 & 25 & 50 & 100 \\
\hline 1998-99 & $\begin{array}{l}\text { (m) } \\
0.3 \\
0.5\end{array}$ & $\begin{array}{l}2.0 \pm 0.04 \mathrm{ab} \dagger \\
2.0 \pm 0.02 \mathrm{a}\end{array}$ & $\begin{array}{l}2.7 \pm 0.05 \mathrm{c} \\
2.2 \pm 0.06 \mathrm{~b}\end{array}$ & $\begin{array}{l}2.6 \pm 0.06 \mathrm{c} \\
2.6 \pm 0.02 \mathrm{c}\end{array}$ & $\begin{array}{l}\ldots \ldots \ldots \\
3.3 \pm 0.12 \mathrm{e} \\
2.9 \pm 0.06 \mathrm{~d}\end{array}$ \\
\hline 1999-00 & $\begin{array}{l}0.3 \\
0.5\end{array}$ & $\begin{array}{l}1.6 \pm 0.04 \mathrm{~b} \\
1.1 \pm 0.02 \mathrm{a}\end{array}$ & $\begin{array}{l}1.9 \pm 0.03 \mathrm{c} \\
1.6 \pm 0.06 \mathrm{~b}\end{array}$ & $\begin{array}{l}2.0 \pm 0.02 \mathrm{c} \\
2.0 \pm 0.03 \mathrm{c}\end{array}$ & $\begin{array}{l}2.0 \pm 0.02 \mathrm{c} \\
2.4 \pm 0.06 \mathrm{~d}\end{array}$ \\
\hline
\end{tabular}

$\lceil$ Within each season, means followed by a different letter are significantly different $(\mathrm{P}<0.05)$ according to the Least Significant Difference Test.

tion, 1999-2000 spring yields were similar or greater at 0.3 than $0.5 \mathrm{~m}$ row spacing (Table 2). Narrower row spacings on herbaceous crop and perennial grass species may lead to less competitive, reduced detrimental effects from weeds on dry matter production, and contribute to greater soil cover which in turn may reduce soil erosion (Young 1956, Akobundu and Ahissou 1985, Muir et al. 2001).

Table 3. Summer dry matter yields as influenced by row spacing, and method and $\mathbf{N}$ fertilization rates in 1998-99 and 1999-00. Values are means \pm 1 standard error.

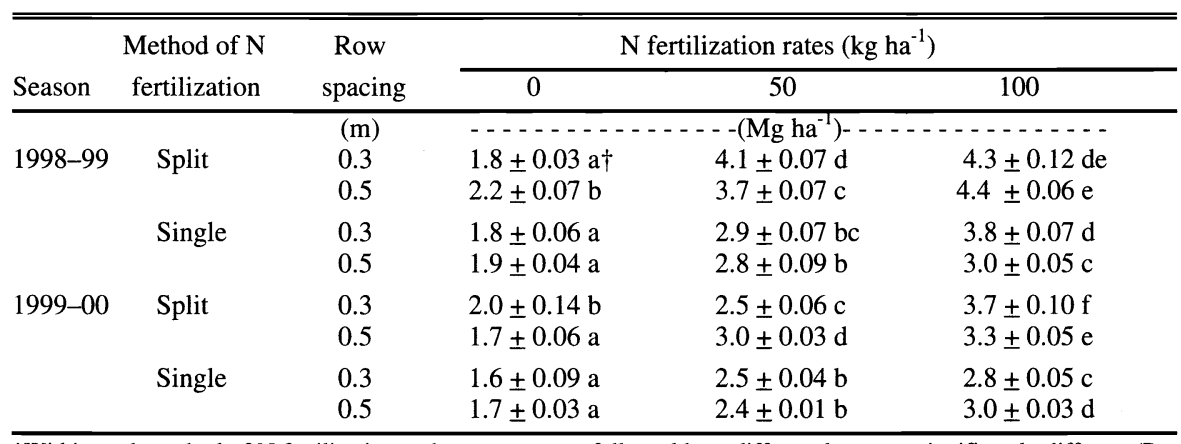

†Within each method of $\mathrm{N}$ fertilization and season, means followed by a different letter are significantly different $(\mathrm{P}<$ 0.05 ) according to the Least Significant Difference Test. 
Results obtained regarding the method of fertilization of $D$. eriantha have been contradictory (Rethman 1987, Pieterse and Rethman 1995, Veneciano and Terenti 1997). Present study demonstrated that dry matter yields of this species were greater when $\mathrm{N}$ application was split than when it was applied at once, which may be associated with better fertilizer utilization efficiency. It is likely that fertilizer fractioning during the growing season diminishes $\mathrm{N}$ losses through ammonia volatilization and/or leaching (Vlek et al. 1981, Garwood 1988, Mazzarino et al. 1998). Application costs, however, double when the same amount of fertilizer is applied at 2 different times rather than at once during the growing season. This study also showed that there was not a clear effect of row spacing on dry matter yield (e.g., in 1998-1999: Table 3).

Fertilization increased $(\mathrm{P}<0.05)$ total annual dry matter yields in all treatments during both seasons, although differences between 50 and $100 \mathrm{~kg} \mathrm{ha}^{-1}$ were not always significant (Table 4). Increased dry matter production in $D$. eriantha after $\mathrm{N}$ fertilization has been observed under different environmental conditions, using various sources and rates of $\mathrm{N}$ fertilizer, and after fertilizing at different times during its growing season (Pieterse and Rethman 1995, Veneciano and Terenti 1997, Gargano et al. 2001a). In fact, N application appears necessary to obtain dry matter yields greater than those found on unfertilized controls (mean $=3.5 \mathrm{Mg}$ $\mathrm{ha}^{-1}$ ). In a recent 4-year study, Gargano et al. (2001b) reported an average dry matter yield of $3.6 \mathrm{Mg} \mathrm{ha}^{-1}$ at the same experimental site when no $\mathrm{N}$ was applied. Some studies have reported on $\mathrm{N}$ fertilization rates which are economically feasible for this species (Grunow and Rabie 1985, Rethman 1987). Similar N rates to those used in our study increased dry matter yields in Eragrostis curvula, another perennial tussock grass species in semiarid Argentina (Hernández 1991). Average dry matter yields were sufficiently greater under split than single $\mathrm{N}$ fertilization during the 1998-1999 summer as to obtain greater $(\mathrm{P}<0.05)$ total annual dry matter yields (Table 4). During the second season, however, average dry matter yield differences among fertilization methods were not as great so that total yields were similar $(\mathrm{P}>0.05)$.

\section{In Vitro Dry Matter Digestibility}

There was no interaction $(\mathrm{P}>0.05)$ between season and treatment for spring, summer or mean annual IVDMD. As a result, average values for both seasons are

Table 4. Total dry matter yields as influenced by row spacing, and method and $\mathrm{N}$ fertilization rates in 1998-99 and 1999-00. Values are means \pm 1 standard error.

\begin{tabular}{|c|c|c|c|c|c|}
\hline \multirow[b]{2}{*}{ Season } & \multirow{2}{*}{$\begin{array}{l}\text { Method of N } \\
\text { fertilization }\end{array}$} & \multirow{2}{*}{$\begin{array}{c}\text { Row } \\
\text { spacing }\end{array}$} & \multicolumn{3}{|c|}{$\mathrm{N}$ fertilization rates $\left(\mathrm{kg} \mathrm{ha}^{-1}\right)$} \\
\hline & & & 0 & 50 & 100 \\
\hline \multirow[t]{2}{*}{ 1998-99 } & Split & $\begin{array}{l}(\mathrm{m}) \\
0.3 \\
0.5\end{array}$ & $\begin{array}{l}3.8 \pm 0.07 \mathrm{a} \dagger \\
4.0 \pm 0.02 \mathrm{~b}\end{array}$ & $\begin{array}{l}--\left(\mathrm{Mg} \mathrm{ha}^{-1}\right)- \\
6.7 \pm 0.11 \mathrm{~d} \\
5.9 \pm 0.09 \mathrm{c}\end{array}$ & $\begin{array}{l}6.7 \pm 0.04 \mathrm{~d} \\
7.0 \pm 0.07 \mathrm{e}\end{array}$ \\
\hline & Single & $\begin{array}{l}0.3 \\
0.5\end{array}$ & $\begin{array}{l}3.9 \pm 0.06 \mathrm{a} \\
4.0 \pm 0.08 \mathrm{a}\end{array}$ & $\begin{array}{l}5.7 \pm 0.11 c \\
5.4 \pm 0.09 b\end{array}$ & $\begin{array}{c}7.1 \pm 0.08 \mathrm{e} \\
6.0 \pm 0.08 \mathrm{~d}\end{array}$ \\
\hline \multirow[t]{2}{*}{$1999-00$} & Split & $\begin{array}{l}0.3 \\
0.5\end{array}$ & $\begin{array}{l}3.6 \pm 0.09 \mathrm{~b} \\
2.7 \pm 0.10 \mathrm{a}\end{array}$ & $\begin{array}{l}4.4 \pm 0.08 c \\
4.6 \pm 0.04 c\end{array}$ & $\begin{array}{l}5.5 \pm 0.12 \mathrm{~d} \\
5.3 \pm 0.09 \mathrm{~d}\end{array}$ \\
\hline & Single & $\begin{array}{l}0.3 \\
0.5\end{array}$ & $\begin{array}{l}3.3 \pm 0.07 \mathrm{~b} \\
2.9 \pm 0.02 \mathrm{a}\end{array}$ & $\begin{array}{l}4.7 \pm 0.05 \mathrm{~d} \\
4.4 \pm 0.04 \mathrm{c}\end{array}$ & $\begin{array}{l}4.9 \pm 0.04 \mathrm{~d} \\
5.5 \pm 0.03 \mathrm{e}\end{array}$ \\
\hline
\end{tabular}

$\uparrow$ Within each method of $\mathrm{N}$ fertilization and season, means followed by a different letter are significantly different $(\mathrm{P}<$ 0.05 ) according to the Least Significant Difference Test.

reported. Spring IVDMD differed $(\mathrm{P}<$ 0.05 ) with fertilization rates but not with row spacings (Table 5). Unfertilized controls showed a lower $(\mathrm{P}<0.05)$ IVDMD than any of the fertilized treatments. The highest value was obtained when applying $100 \mathrm{~kg} \mathrm{ha}^{-1} \mathrm{~N}$ but it was only $25 \mathrm{~g} \mathrm{~kg}^{-1}$ greater than the average of the other 2 rates of $\mathrm{N}$ fertilizer.

During summer, only the main effects rate of $\mathrm{N}$ fertilizer and row spacing were significant $(\mathrm{P}<0.05)$. Row spacing only differed $(\mathrm{P}<0.05)$ when $\mathrm{N}$ was applied once. Differences among average values of summer IVDMD under 0,50 , and 100 $\mathrm{kg} \mathrm{ha}^{-1} \mathrm{~N}$ (Table 6) followed the same pattern as observed for spring (Table 5). Other workers have reported a small or even no response of IVDMD to fertilization under rates of $\mathrm{N}$ fertilizer, similar or greater than those used in our study, applied on forage at different phenological stages (Grunow and Rabie 1985, Veneciano and Terenti 1997) or on deferred pastures (Gargano et al. 2001a).

Nitrogen fertilization rates and row spacing interacted significantly $(P<0.05)$ within each method of fertilization for mean annual IVDMD (Table 7). As verified for spring and summer sampling, IVDMD increased as $\mathrm{N}$ fertilization rates increased (Table 7). Under split fertilization, erratic responses were obtained when comparing row spacings (Table 7). When fertilizer was applied at one time, however, IVDMD was greater $(\mathrm{P}<0.05)$ at 0.5 than at $0.3 \mathrm{~m}$ row spacing only in the 0 and $100 \mathrm{~kg} \mathrm{ha}^{-1} \mathrm{~N}$ treatments (Table 7).

Effects of treatments on digestible dry matter yields are not presented because they were practically identical to those reported for dry matter yields.

Table 5. In vitro dry matter digestibility in spring as influenced by row spacing and $\mathbf{N}$ fertilization rates. Within each row spacing, values are averaged from both seasons. Values are means \pm 11 standard error.

\begin{tabular}{|c|c|c|c|c|}
\hline \multirow{2}{*}{$\begin{array}{l}\text { Row } \\
\text { spacing }\end{array}$} & \multicolumn{4}{|c|}{$\mathrm{N}$ fertilization rates $\left(\mathrm{kg} \mathrm{ha}^{-1}\right)$} \\
\hline & 0 & 25 & 50 & 100 \\
\hline (m) & $\ldots \ldots$ & $\ldots \ldots$ & $\ldots \ldots$ & $\ldots \ldots \ldots$ \\
\hline 0.3 & $590 \pm 2.2$ & $634 \pm 2.0$ & $644 \pm 2.3$ & $664 \pm 2.5$ \\
\hline 0.5 & $613 \pm 2.9$ & $640 \pm 1.8$ & $646 \pm 2.1$ & $669 \pm 2.4$ \\
\hline Average & $602 \pm 2.6$ a $\dagger$ & $637 \pm 1.9 b$ & $645 \pm 2.2 b$ & $666 \pm 2.4 c$ \\
\hline
\end{tabular}

$†$ Means followed by a different letter are significantly different $(\mathrm{P}<0.05)$ according to the Least Significant Difference Test.

Table 6. In vitro dry matter digestibility in summer as influenced by row spacing and $\mathbf{N}$ fertilization rates within each method of $\mathrm{N}$ fertilization. Values are averaged from both seasons. Values are means \pm 1 standard error.

\begin{tabular}{lccccc}
\hline & \multirow{2}{*}{$\begin{array}{c}\text { Method of } \mathrm{N} \\
\text { Season }\end{array}$} & \multirow{2}{*}{$\begin{array}{c}\text { Row } \\
\text { fertilization }\end{array}$} & spacing & \multicolumn{2}{c}{ N fertilization rates $\left(\mathrm{kg} \mathrm{ha}^{-1}\right)$} \\
\cline { 3 - 5 } Split & $(\mathrm{m})$ & 0 & 0 & 50 & 100 \\
& 0.3 & $602 \pm 2.8$ & $634 \pm 4.1$ & $665 \pm 7.7$ & $634 \pm 5.0 \mathrm{a} \dagger$ \\
Single & 0.5 & $609 \pm 1.5$ & $628 \pm 6.9$ & $648 \pm 3.3$ & $628 \pm 4.4 \mathrm{a}$ \\
& 0.3 & $586 \pm 4.9$ & $620 \pm 4.1$ & $636 \pm 2.0$ & $614 \pm 5.1 \mathrm{a}$ \\
\multirow{2}{*}{ Average } & 0.5 & $614 \pm 2.0$ & $632 \pm 4.5$ & $662 \pm 6.9$ & $636 \pm 3.8 \mathrm{~b}$ \\
\hline
\end{tabular}

$\dagger$ Within each method of $\mathrm{N}$ fertilization, row ( $\dagger$ ) and column ( $\ddagger)$ means followed by a different letter are significantly dif- 
Table 7. Mean annual in vitro dry matter digestibility as influenced by row spacing and $\mathrm{N}$ fertilization rates within each method of $\mathbf{N}$ fertilization. Values are averaged from both seasons. Values are means +1 standard error.

\begin{tabular}{lccccc}
\hline \hline & \multirow{2}{*}{$\begin{array}{c}\text { Method of } \mathrm{N} \\
\text { Seaason }\end{array}$} & $\begin{array}{c}\text { Row } \\
\text { fertilization }\end{array}$ & spacing & 0 & \multicolumn{2}{c}{$\mathrm{N}$ fertilization rates $\left(\mathrm{kg} \mathrm{ha}^{-1}\right)$} \\
\cline { 5 - 6 } Split & $(\mathrm{m})-$ & $-\ldots \ldots$ & 50 & 100 \\
& 0.3 & $597 \pm 2.9 \mathrm{a} \dagger$ & $634 \pm 2.3 \mathrm{c}$ & $661 \pm 6.4 \mathrm{e}$ \\
Single & 0.5 & $610 \pm 2.3 \mathrm{~b}$ & $632 \pm 3.5 \mathrm{c}$ & $648 \pm 1.7 \mathrm{~d}$ \\
& 0.3 & $588 \pm 4.0 \mathrm{a}$ & $627 \pm 1.7 \mathrm{c}$ & $648 \pm 1.8 \mathrm{~d}$ \\
& 0.5 & $615 \pm 2.9 \mathrm{~b}$ & $638 \pm 4.6 \mathrm{~cd}$ & $665 \pm 6.9 \mathrm{e}$ \\
\hline
\end{tabular}

$\dagger$ Within each method of $\mathrm{N}$ fertilization, row ( $\dagger$ ) and column ( $\ddagger)$ means followed by a different letter are significantly different $(\mathrm{P}<0.05)$ according to the Least Significant Difference Test.

\section{Conclusions}

Dry matter yields increased when $D$. eriantha was fertilized with $\mathrm{N}$. Results suggest use of a $\mathrm{N}$ fertilization rate between 50 and $100 \mathrm{~kg} \mathrm{ha}^{-1}$. Greater dry matter yields were obtained when $\mathrm{N}$ fertilization was split than when it was applied at 1-time. Row spacing did not affect dry matter yield. This encourages seeding of $D$. eriantha in 0.3 rather than $0.5 \mathrm{~m}$ interrow spacing which would contribute to reduced competition from weeds and increased soil cover. In vitro dry matter digestibility increased with $\mathrm{N}$ fertilization but these increases were of a small magnitude which makes doubtful its biological and/or economical relevance.

\section{Literature Cited}

Akobundu, I.O. and A. Ahissou. 1985. Effect of interrow spacing and weeding frequency on the performance of selected rice cultivars on hydromorphic soils of West Africa. Crop Protection 4:71-76.

Barnes, R.F. 1966. The development and application of in vitro rumen fermentation techniques. Proc. X Internat. Grasslands Congr., pp. 434-438, Helsinki, Finland.

Becker, G.F., C.A. Busso, T. Montani, A.L. Orchansky, R.E. Brevedan, M.A. Burgos, and A.C. Flemmer. 1997. Effects of defoliating Stipa tenuis and Piptochaetium napostaense at different phenological stages: tiller demography and growth. J. Arid Environ. 35: 251-268.

Dannhauser, C.S. 1991. The herbage yield and quality of three grass species on two marginal maize soils at Potchestroom. J. Grassl. Soc. S. Afr. 83:120-121.

Farnham, D.E. 2001. Row spacing, plant density, and hybrid effects on corn grain yield and moisture. Agron. J. 93:1049-1053.

Gargano, A.O., M.A. Adúriz, and M.C. Saldungaray. 2001a. Yield and quality of fertilized deferred forage of Eragrostis curvula and Digitaria eriantha. J. Arid Environ. 47:181-189.

Gargano, A.O., M.A. Adúriz, H.M. Arelovich, and M.I. Amela. 2001b. Forage yield and nutritive value of Eragrostis curvula and Digitaria eriantha in south semi-arid Argentina. Trop. Grasslands 35:161-167.

Garwood, E.A. 1988. Water deficiency and excess in grassland: the implications for grass production and for the efficiency of use of N. p. 24-41. In: E. Wilkins (ed) Nitrogen and water use by grassland, Proc. of Colloquium to mark the retirements from the Inst. for Grassl. and Anim. Prod. of E.A. Garwood and J. Morrison. Hurley, United Kingdon.

Grunow, J.O. and J.W. Rabie. 1985. Production and quality norms of certain grass species for fodder flow planning: Pretoria area. J. Grassl. Soc. S. Afr. 2: 23-28.

Grunow, J.O., P.A. Pieterse, and D.E. Borlinghaus. 1984. A comparison of highveld fodders and fodder flows for growing out longyearling steers. J. Grassl. Soc. S. Afr. $1: 25-29$

Hernández, O.A. 1991. Manejo del cultivo y respuesta al pastoreo, pp. 277-322. In: El Pasto Llorón. Su Biología y Manejo. Fernández, O.A., R.E. Brevedan y A.O. Gargano (Eds). CERZOS-UNS.

Jacobsen, J.S., S.H. Lorbeer, H.A.R. Houlton, and G.R. Carlson. 1996. Nitrogen fertilization of dryland grasses in the Norhtern Great Plains. J. Range Manage. 49:340-345.

Kruger, J.A. and I.B.J. Smit. 1974. The effect of seeding rate spacing and fertilization of the hay yield of Eragrostis curvula in the eastern Free State. South Africa Dept. Agr. Tech. Serv. Tech. Commun. 120: 1-5.

Mazzarino, M.J., M.B. Bertiller, C. Sain, P. Satti, and F. Coronato. 1998. Soil nitrogen dynamics in northeastern Patagonia steppe under different precipitation regimes. Plant Soil 202:125-131.

Muir, J.P., M.A. Sanderson, W.R. Ocumpaugh, R.M. Jones, and R.L. Reed. 2001. Biomass production of 'Alamo' switchgrass in response to nitrogen, phosphorus, and row spacing. Agron. J. 93:896-901.

Natr, L. 1976. The effect of plant spacing on the assimilation apparatus and yield in spring barley. Rostlinna-Vyroba 22: 577-591.

Pieterse, P.A. and N.F.G. Rethman. 1995. Research note: Level of nitrogen fertilization and the dry matter yield of Digitaria eriantha cv. Irene in the Trasnvaal middleveld. Afr. J. Range For. Sci. 12:87-88.
Rethman, N.F.G. 1987. The effect of form and level of nitrogen fertilization on the yield of Digitaria eriantha Steud. J. Grassl. Soc. S. Afr. 4: 105-108.

Rethman, N.F.G., P.S. Venter, and J.P. Lindeque. 1997. Influence of soil water availability on the above and below ground phytomass of five subtropical grass species. Appl. Plant Sci. 11: 29-30.

Sánchez, L.F. and H. R. Kruger. 1981. Los suelos del campo Palíhue de la Universidad Nacional del Sur. Bahía Blanca, Argentina, $10 \mathrm{pp}$.

Servicio Meteorológico Nacional. 2000. Estadísticas Climatológicas. Buenos Aires, Argentina, $20 \mathrm{pp}$.

Steel, R.G.D. and J.H. Torrie. 1988. Bioestadística. Principios y Procedimientos. McGraw-Hill/Interamerica, México.

Stout, D.G., J. Hall, B. Brooke, and A. McLean. 1981. Influence of successive years of simulated grazing (clipping) on pinegrass growth. Can. J. Plant Sci. 61:939-943.

Stritzler, N.P., C.M. Rabotnicof, H. Lorda, and A. Pordomingo. 1986. Evaluación de especies forrajeras estivales en la región semiárida pampeana. III. Digestibilidad y consumo de Digitaria eriantha y Bothriochloa intermedia bajo condiciones de diferimiento. Rev. Arg. Prod. Anim. 6:67-72.

USDA. 1999. Soil Taxonomy: A Basic System of Soil Classification for Making and Interpreting Soil Surveys. Second Edition. USDA: Washington, D.C.

Van Vuuren, B.G.J., J.W. Cilliers, J.J. Jaarsma, and H.J. Van der Merwe. 1997. The potential of Digitaria eriantha Steud. as summer pasture crop for growing sheep. So. Afr. J. Anim. Sci. 27:59-63.

Veneciano, J.H. and O.A. Terenti. 1997. Efectos de la defoliación y la fertilización nitrogenada en el rendimiento y calidad de Digitaria eriantha Steudel subsp. eriantha cv. Irene. Rev. Fac. Agron. UNLPam. 941-56.

Vlek, P.L., I.R.P. Fillery, and J.R. Burford. 1981. Accession, transformation, and loss of nitrogen in soils of the arid region. Plant Soil 58:133-175.

Young, V.A. 1956. The effect of the 19491954 drought on the ranges of Texas. J. Range Manage. 9:139-142. 